\title{
THE TEACHER AND THE STATE
}

By Dr. J. H. KIRKLAND, Chancellor of Vanderbilt University, Nashville, Tennessee

The attention of educational leaders in the South during past years has been largely fixed on one problem-the need of universal primary education. No one will maintain that this need has been unduly emphasized or immoderately pressed. Every investigation that has been made has helped to establish the fact that a shameful degree of illiteracy prevails in the South among both the white and black races. That this degree of illiteracy is not so bad as it might be, or not so bad as it has been, does not content us. Honesty and candor compel us to admit that the present condition of education, especially so far as regards the white population of the South, is discreditable to us as a people and is without satisfactory excuse. We cannot excuse the deficiencies of 1903 by the history of I863. Our wilderness has not lasted forty years; in this time we have passed from desolation to plenty and two generations have grown to manhood. But the true historian will always find in the past an explanation, if not an excuse, for the present, and so it is in this case.

Perhaps the most terrible feature of the great struggle through which the South passed was the depression that followed. Our people were face to face, not only with the ashes of their homes and the graves of their dead, but with the wreck and ruin of the whole social fabric which they had built up. In the desolation of that hour they felt stunned and bewildered. Their faces were set to the past and their hearts refused to be comforted; as the sea bird with broken wing disdains the fields of plenty and stalks the barren shore, with eye ever fixed on the ocean wave that was its home, and from which an unkind fate has driven it. For this attitude the South has been judged severely and harshly, and yet it was entirely natural. The next important fact to be remembered is the extreme impoverishment of the South. This was not a passing discomfort of a few years, but the fixed status of this section for twenty long years. During this period the assessed valuation of property steadily declined from more than five thousand million dollars to less than two thousand 
million. No wonder we talk about the new South; of the old South nothing was left save its barren hillsides washed and scarred by four years of neglect. Statistics do not help much here. To strangers they tell but little, and we who passed through that period do not need them; our memories need no reminder. We know what it means to enter into association with those heavenly powers whose fellowship, as Goethe tells us, can only be attained by those who have eaten their bread with tears and spent the solitary watches of the night in silent suffering. I would not dwell on these things; they are only alluded to because they are essential in order to understand the problems with which we are concerned to-day.

Since I880 the recuperation of the South has been rapid and remarkable. Our industrial revival has been so frequently commented on that it is familiar to all. The increase in value of farms, farm products, implements and machinery, live stock, cotton mills, coal mines, iron foundries, railroads, has far surpassed the general average of increase for the country at large and has been a surprise even to ourselves. The South is throwing off the burden of its poverty. Her orchards are loaded with fruit, her gardens with vegetables, her fields are white with a cotton crop worth four hundred million dollars, mines are opened on every hillside, furnace fires lighted in every valley, and the hum of machinery is heard in every village and by every stream. We are sending granite to New England, iron to Pennsylvania, marble to Italy, and "coals to Newcastle." But in the midst of this growing prosperity our progress in educational matters remains discreditable. The expenditure per capita of population has increased, but we are actually spending less for each pupil in attendance on public schools than was spent in 1870 .

We recognize, therefore, the timeliness of the great movement which the Southern Education Board has organized. We are thankful for every paper than can be written, for every investigation that can be made, for every word of warning, of entreaty, of encouragement that can be uttered. In that union of effort we realize the oneness of the American people. The study of abstract problems promotes differences. The Northern point of view differs materially from the Southern in regard to some points in our life and civilization. Manufacturers of cheap politics parade these differences and accentuate them. An irresponsible journalism 
arrays one section against another; but when we join forces in the great work of education, and see each other face to face, eye to eye, it then becomes clear that there are no material differences, that we all alike desire and are striving after the same things largely in the same way. Our problems in the South are yours, our interests are yours; yours, too, are our successes and yours our failures.

"For mankind are one in spirit, and an instinct bears along, Round the earth's electric circle, the swift flash of right or wrong;

Whether conscious or unconscious, yet Humanity's vast frame Through its ocean-sundered fibres feels the gush of joy or shame:

In the gain or loss of one race all the rest have equal claim."

Perhaps it is now in order to emphasize for a moment the supreme importance of the teacher in this work we are planning for the South. In doing so we do not detract from the importance of every other agency alluded to, but before them all and above them all I place as the supreme educational need of the South at this time, competent teachers. All the problems of the school are in the end the problem of the teacher. The schoolhouse is but a body, the teacher is the soul; even books are to most boys and \&irls dead rubbish until vitalized by the presence of an interpreter. We have had much to say recently of consolidating small schools into large ones, with large buildings and long terms. In a city of one of the oldest countries of the Old World is a school well consolidated, for it has I0,000 pupils; its term is long, for it knows no regular vacation; its pupils are earnest, for many of them live on the crumbs that fall from the table of plenty, but no light breaks for the pupil, or for the world from the Mohammedan University of Cairo. On the other hand, without a building, without endowment, Athens became the schoolmistress of the world. Socrates taught on street corners and his lessons are still being learned; Plato in an olive grove, and Zeno in a public porch; greater than all, Jesus of Nazareth taught by lake or by roadside, in the valley or on the mountain top. In all the ages past, universities have been great by reason of great teachers. Till recently they have had few buildings, and meager equipment outside of libraries, but for seven hundred years they have been the source of life and of light; they have outlived wars and revolutions, they have seen cities crumble, nations die, dynasties pass away, while they have lived on. Discarding their 
own vernacular, they have spoken in a world language. The birth of our oldest universities, as at Salerno, Naples, Bologna and Paris, was due to the influence of great teachers, who, in some dismal rented hall, or in their own homes, spoke the words that drew the world to hear. And yet even universities are prone to forget these things at the present time. We go on erecting magnificent buildings, and often fail to put in them men of power. Benefactors prefer to erect buildings rather than to pay teachers. And in school work we photograph the log schoolhouse and tear it down for a new and handsome frame or brick building, but we put the same teacher into the new and leave him to his same pernicious routine of unfruitful labors. This is not sound policy, either from an educational or business standpoint. It would be poor policy in a railroad company to expend large sums on roadbed, engines and handsome rolling stock, while they leave trains to be run by brakemen instead of trained engineers. It would be poor policy for a city to deepen its harbors, erect light-houses, build great ocean steamers, and leave ignorant pilots to guide them into the breakers and dash the treasures of freight and passengers on the rocks

There are in this country about half a million teachers employed in public schools. Is it too much to say that a large proportion of them are unfit for this responsible position? If I were afraid to say so, I could easily quote to this effect statements made in every section by leaders in every department of educational work. Go to the office of any state superintendent and read the letters received from his teachers; look over the examination papers on which certificates are granted; go to the county institutes and work with the teachers present, remembering that the best are present, while the most inefficient stay away. It is not necessary to go into details here. It would be easy to wing my words with sarcasm or ridicule, but I forbear. I am speaking of my brothers and sisters, my colleagues in a great calling, and there is occasion for tears rather than laughter. Two years ago at the meeting of the Department of Superintendence of the National Educational Association, Mr. Frank L. Jones, superintendent of education for the state of Indiana, presented these figures based on information secured concerning 20,662 teachers in ten states. These ten states were: Indiana, Kansas, Michigan, Missouri, New York, Ohio, Pennsylvania, Wisconsin, Illinois and Iowa. Of these 20,662 teachers, 2,450 were teaching 
without previous experience, 4,880 had only a common school education, and 8,600 had not studied beyond the high school. If this state of affairs exists in the states whose system of public schools is held up to us as a model, what would the records of the Southern states show? In my own state of Tennessee out of 9,396 certificates issued in 1900, 7,086 were third grade, and few, if any, of these teachers had had any instruction in school methods. This is a typical instance of Southern conditions. What can be done to remedy this state of affairs? One view often expressed is that this matter will settle itself as soon as longer school terms and better pay are provided. But the president of the Conference for Education in the South, in his annual address one year ago, asked this question: "If millions of money were ready, where are the teachers? Is there not here a new question for pedagogy to solve?" Our great educational revival will bring us longer terms. About this there can be no doubt. The writing on the wall is plain and cannot be misinterpreted. This change will come more rapidly than some of us have dared to hope, but will we have an improved order of teachers ready to meet the new conditions? This inquiry we can certainly answer in the negative unless we begin now to make preparation. This problem is worthy the most serious thought at the present time, and calls for more active efforts than have hitherto been put forth. There are two points to be considered here: one is, to improve the supply of teachers we now have; the other, to get ready a new and better trained supply to take their places. The first task can only be accomplished in ways somewhat irregular. There is no process by which the teacher can be born again or be made to begin over again, but by county and state institutes, by reading circles, by correspondence courses, and by summer schools great improvement can be brought about in a condition well-nigh intolerable. The pressure of school officials, county and state, can aid much in this work. But let us not overrate these means of grace. They are only palliative, not radically curative. More permanent results will be secured by the establishment of normal schools and by the improvement of those already existing. Even high schools can give normal courses to prospective teachers, and our colleges and universities should lend their assistance by establishing chairs of pedagogy and providing practical as well as theoretical work along this line. We have not yet begun to take hold of this question seriously 
in the South. Some things already done must be undone,--some institutions using the name of normal schools, normal colleges and normal universities must be banished from the list of reputable institutions and forced to close their doors or mend their ways,- -and all of us must try to do better and reach higher standards than those already attained.

This work belongs primarily to the state, and the state alone is able to carry it out. It is of as great importance to the state as the training of sailors and soldiers, and the licensing of teachers should be as carefully guarded as the licensing of lawyers and doctors. The Greek word for state has given us two words that indicate two spheres of activity-unfortunately, neither of them the highest: one is police and the other politician. One of these indicates that part of state activity that belongs to ourselves; the other that part which we apply to our neighbors. But we are not willing to admit that the supreme function of the state is to be found in the struggle to rule, whether of individuals or of parties, nor yet in the restraint of open violence or crime. No doubt the protection of life and property is one of the first duties of organized society, but even this task cannot be successfully performed by the soldier or policeman. Property is lost not through robbery alone; life is endangered in other ways than by violence. Ignorance is the great destroyer of property and of life. A few microbes cause more loss of life in one year than there have been homicides in a century; a half dozen insects will inflict greater financial loss in the coming summer than robbers have occasioned in a generation. Even put on the lowest plane and expressed in the fewest terms, the duties and obligations of the state move out irresistibly into the field of education. No state has ever been truly great whose rule was merely that of the sword. Tamerlane conquered a kingdom greater than Rome's in the time of Trajan, but it passed away as a pebble dropped into the sea. The power that endures is not that of the sword, but of the spirit: the state must build its enduring habitations, not in the slaves over which it rules, but in the lives of its citizens whom it raises to be a race of kings. To do this, attention must be given to the development of a complete educational system. The state cannot rely on outside agencies. The home is the first school, but the state cannot be satisfied with that. The pulpit and the press are educative in their influence, but the state cannot be content with these. Self-interest or 
associated effort may arouse certain activities and call forth institutions erroneously called private schools, private academies, or private universities. To all of these the state should lend a sympathetic support, for they are all doing the work of the state, but it may not allow the great cause of education to rest here. Beyond all this the state must go, recognizing its obligations to every child, seeing in every life the possibility of a Divine incarnation, and finding in the up-lift of the individual and the social whole, its most glorious privilege and most urgent duty.

This is the work to which the teacher must largely contribute, and for these duties he must be prepared. It is not merely a question of money. The whole profession must be elevated. The teaching profession inherits disabilities. We take our name from the slave that led the child to school, and often the teacher himself has been a slave. Slowly through the ages he has pulled himself up, and even yet he bears the mark of inferior service and feels the sting of social reproach. Read the multitude of confessions brought together in a late number of the World's Work and see if I do not speak the truth. The old "Town Book" gives the following as the duties of the schoolmaster in early New England: "I. To act as court messenger. 2. To serve summonses. 3. To conduct certain ceremonial services of the Church. 4. To lead the Sunday school. 5. To ring the bell for public worship. 6. To dig the graves. 7. To take charge of the school. 8. To perform other occasional duties." A somewhat more graphic description of the diversified labors of the early teacher in rural districts may be found in the following advertisement of a "Parson's Clerk," whose services were rendered in the famous Lake District of England. The undersigned "reforms ladies and gentlemen that he draws teeth witout waiting a moment, blisters on the lowest terms and fysicks at a penny. Sells God-father's cordial, cuts corns, and undertakes to keep anybody's nails by the year or so on. Young lades and gentelmen tort their grammer language in the neatest possible manner; also great care taken of their morals and spellin. I teeches joggrefy and all them outlandish things." This was the same clerk who was said to have given the following notice to the assembled congregation: "There'll be nae service in this church for ' $m$ ' appon a matter o' fower weeks, as parson's hen is sitting in t' pulpit."

In contrast with this, let us take the statement of Plato, who 
says in regard to the minister of education that "of all the great offices of state, this is the greatest. He should be elected who, of all the citizens, is in every respect the best." To the teacher society entrusts its highest interests. The true teacher is the high priest of humanity; he is to childhood the interpreter of God and nature, he saves each generation from savagery, he gives the child his inheritance in all the achicvements of the human race, he voices the wisdom of the past and the prophecies of the future. To this work he should come with a fullness of knowledge, for he bears the riches of God's universe; with skill in method, for he handles not implements of stone and wood, but human minds and hearts; with the life-giving power of a great soul, that vitalizes all it touches and pours itself out with the largess of divinity, for only thus can he quicken the soul of man. 